\title{
CORPORATE SOCIAL RESPONSIBILITY IN INDONESIA:QUIXOTIC DREAM OR CONFIDENT EXPECTATION?
}

\author{
Subiyanto \\ Universitas Wijaya Putra Surabaya \\ subiyanto_m@yahoo.com
}

\begin{abstract}
During the past decade there has emerged, in North America and Western Europe in particular, a fairly powerful movement to improve the social and environmental performance of large corporations and their affiliates and suppliers in developing countries. By examining the case of Indonesia, this paper looks at how effective this approach has been.

The discussion on codes of conduct presents both civil society and TNC perspectives on the implementation, achievements and limitations of such initiatives, codes are fundamentally flawed for several reasons: they may serve to place corporations outside of the national regulatory system and bypass the tripartite negotiation system that was one of the major labour reforms of recent years.

When viewed in the context of culture, economic and political development, and turmoil in Indonesia, the author concludes that CSR remains an ideal. The current transformation is bringing instability, fear and violence. In such a context, it is hard to consider something as abstract as CSR. It is timely, however, to begin to put into place the institutions, educational foundations and management training which are needed for business and political reform, and from which CSR may be a spin-off.

While it is fair to say that CSR makes a positive contribution to the human rights of those working in TNCs, it is also fair to say that it only makes a difference to those few corporations targeted by consumers or who are already thinking ethically and responsibly. Other industries are not so well inclined.

That being said, the after-shock of the Indonesian economic crisis has required a re-evaluation of both economic and investment policy, and the way business is run in Indonesia. The previous short-term thinking may have to make way for the type of longer-term pragmatic and visionary thinking required by genuine CSR and supported by Islamic business principles. While CSR may benefit a small minority of Indonesia's workers and those whose lives intersect with TNCs, the development of and adherence to a fair system of law and institutional reform would benefit all. Without such changes, CSR is likely to remain as quixotic dream.
\end{abstract}

Keywoords: CSR, TNC, economic crisis, business

\section{INTRODUCTION}

The current global discourse on corporate social responsibility (CSR) emphasizes its cultural universality and benefits (Darley and Johnson,
1993; Quazi and O’Brien, 2000). In practice, there are numerous obstacles to achieving corporate responsibility, particularly in many developing countries where the institutions, standards and 
appeals systems, which give some life to CSR in North America and Europe, are relatively weak. This paper describes the experience of promoting CSR in Indonesia and its relevance to that economy and society. Particular attention is focused on codes of conduct and environmental stewardship.

When discussing the scope or socioeconomic impact of CSR in the Indonesian context, it is important to know a little of the history of contemporary economic culture. While transnational corporations (TNCs) have been in Indonesia for many years, CSR is a relatively new concept and practice. Having been generated in Europe and the United States as an answer to the perceived excesses of corporate power, CSR standards and initiatives are based on loosely defined social norms and stakeholder values that stem from Western cultural values. As a result, foreign investors and multilateral donors are increasingly demanding that developing countries provide some degree of national as well as corporate transparency and accountability.

Much of the analysis contained in this paper is based on media reports and published works. Given the lack of systematic research in Indonesia on this topic, the paper is intended to constitute a preliminary analysis of corporate responsibility issues and concerns. The conclusion sums up the main points to emerge from the paper and reflects on the difficulties of promoting CSR in a nation that has no underpinning of the rule of law or effective way of mobilizing or legitimizing watch-dog bodies such as trade unions and consumer groups.

\section{Indonesian Culture and Corporate Social Responsibility}

In a well-worn but apt metaphor, Indonesian shadow puppet play (wayang kulit) represents the juxtaposition of life, business and art in the country. In no area is this more striking than in relation to CSR. If CSR has any intrinsic value it should not represent awards, glossy reports or audits - in short, artifice - but instead an ethical society, one based on a consistent respect for the value of its people and their rights, as well as their environment, and adherence to and respect for the rule of law. These factors, of course, have to run in parallel with the pursuit of profit.
If the process of improving corporate social and environmental performance is undoubtedly a reflection of broader cultural and societal change, it remains to be seen if, and to what degree, the political and corporate dalangs (puppet masters) will allow the CSR screenplay to control the characters. When watching a wayang, one not only notices the action portrayed on the oil lampilluminated screen, but the artistry of the dalang, the person behind the screen, manipulating the image. The images are ephemeral, but real at the time, and it is the dalang who determines what we see. What follows is a description of how CSR in Indonesia is merely an image presented to a public audience by those working behind the screen.

Some observers consider Indonesia one of the most complex cultures to understand and penetrate. While it embraces modernity (the trappings of which are easily seen in the cities), its business, political and community culture continues to be flavoured by tradition, which is overlaid with the strictures of endemically corrupt authoritarianism. All of these factors affect the acceptance and utility of CSR in the Indonesian context.

The Dutch colonial government formed a seamless blend with the aristocratic Javanese culture during the reign of the Dutch East India Company. This original aristocratic court culture (priyayi) derived from the large sultanates of Java. Over time priyayi reflected the halus nature of the Javanese courts: a refined, unostentatious and selfcontrolled culture. When Soeharto, himself a commoner, became President in 1965 he took on the mantle of priyayi culture and this model became the ideal (Goodfellow, 1997). Indonesia is a widely diverse culture, however, and priyayi is an exclusive rather than inclusive social class. The divide that continues to exist between the masses and the ruling elite is at odds with the social concern implicit in CSR.

CSR requires commitment, long-term thinking and vision from business managers. Faulkner reports that there are still too few trained managers (Faulkner, 1995), adding that promotions and appointments are often accorded to those with political or family connections. The decisions made are those that reflect self or family interest and, in

$$
\text { Ekonomi, Sosial, dan Budaya }
$$


general, are not informed by wider commercial, social or environmental concerns, or regulatory strictures. Despite formal agreements between the government and the World Bank stipulating that the renewal of licenses to practice business was to be contingent on firms presenting alternative plans and changing work practices, the Indonesian Bank granted a further operating license to Barito Pacific. This company is a locally owned logging conglomerate, infamous in Indonesia for its destructive logging, unsafe working conditions, non-compliance with minimum wage requirements and openly polluting practices. As a World Bank official admitted, there is no evidence to show that Barito Pacific, and by implication other big companies, will pursue anything other than business as usual.

The endemic culture of corruption has had the effect of causing widespread cynicism and complicity in a culture used to official dishonesty (Alatas, 1999). This does not bode well for CSR, which requires a high level of monitoring and disclosure. A World Bank official explained, for example, that companies awarded ISO certification for environmental and quality control inevitably reverted to the same old practices while trading on the certification rewarding planning, not performance. Similarly, timber coming from primary forests in Kalimantan is openly labelled and sold as "Made from sustainable plantation forest in Australia". This serves to trivialize and compromise voluntary initiatives that aim to promote corporate environmental responsibility, and to deepen the distrust of citizens and investors in the processes of law.

On the labour side, some cultural factors, in particular the acceptance of one's nasib (fate) and great dependence on income in the absence of any social welfare system, mean that substandard working conditions and a degraded environment are grudgingly accepted by all except the vocal activist minorities. In fact, most are simply pleased to have any form of income and would happily work harder if it meant more income (personal communication, workers in several factories).

While a spirit of reformation continues to pervade the urban industrial zones, it has not yet reached a sufficient level to bring lasting change to what is, in essence, a feudal industrial relations system reflecting priyayi ideals. In a society such as Indonesia where corruption is endemic, a tendency to kleptocracy, fed by contemporary insecurity, also exists (Rossouw, 1998).

The growing influence of Islam, which emphasizes honesty and integrity in business, constitutes a ray of hope that CSR may gain a foothold in Indonesia. Mohammed himself, who was a successful trader, put a lot of store on the place of honour in trade to the point that Islam in effect invented cheques in recognition of the trust that should be integral to business.

While large Chinese-owned businesses, which comprise an important part of the Indonesian economy at all levels, are changing their management systems in line with modern, accountable management practice, the patriarchal structure still exists (Sawarjuwono and Goodfellow, 1997). Most Chinese-owned businesses are set up as limited companies, to minimize outside interference. Their insular style of management is highly personal, enfolding only family members or those known to the family. While CSR aims to incorporate the needs of multi-stakeholder interests, Indonesian/Chinese management styles preclude any interests external to those of the core management group.

\section{Corporate Social Responsibility and Codes of Conduct}

There are several contentious issues and debates surrounding the replication of CSR in developing countries. Key questions are: how appropriate and transferable are the tenets of CSR; and how quickly and comprehensively are they being taken up to make a significant difference to the overall status of workers and environmental preservation?

Threats of trade boycotts in the West, and insistence on monitoring and codes of conduct, have led to tensions between the developed and the developing worlds. After years of interviewing workers in Asia, Kristoff and Wu Dunn argue that

$$
\text { Ekonomi, Sosial, dan Budaya }
$$


sweatshops can play a positive role in wealth creation. They argue that workers view reformist pressure from the West as dangerous because it threatens the viability of their employment. They have an unlikely ally in Paul Krugman, who points out that "A country like Indonesia is still so poor that progress can be measured in terms of how much the average person gets to eat" (Krugman, 1999).

The improvement in calorific intake since 1975 has not been due, he claims, to benign government intervention; rather, it has been the unintended result of the actions of soulless multinationals and rapacious local entrepreneurs whose only concern has been to take advantage of the profit opportunities offered by cheap labour. It is not an edifying spectacle; but no matter how base the motives of those involved, the result has been to move hundreds of millions of people from abject poverty to something still awful but nonetheless better. Krugman insists that international pressure for improved standards in TNCs risks creating a labour elite, with little or no benefit for the greater numbers of poor farmers, day labourers, household help and other informal sector workers.

Certainly workers in TNCs interviewed by this author believe themselves to be fortunate. TNC wages are usually (marginally) above the national minimum, conditions are better than those in domestically owned companies, and workers enjoy the social prestige of making a globally known product. I would contend, however, that the very profitability of TNCs should enable them to pay more and not only take a lead in labour reform but also work toward halting the "race to the bottom".

While most would argue that business ethics are integral to political democracy and economic stability, considerable inertia can prevent anything more than token change. If one uses Quazi and O'Brien's two-dimensional model of corporate responsibility, Indonesia could be placed at the extreme right of the axis, which defines responsibility in the narrowest sense of profit maximization, reducing short-term costs and ignoring longer-term benefits (Quazi and O'Brien, 2000). In essence, this axis starts with the Milton Friedman axiom that the social responsibility of a business is to increase its profits (Friedman, 1970).
In addition, it is expected that all organizations function as they do (or should) in the West, with rational and logical processes underpinning decisions.

The Indonesian economy has always been buoyant, with massive oil reserves and valuable natural resources, such as timber and minerals, in addition to its manufacturing industry. Even during the current period of instability, Indonesia's economy has been growing by 3 to 5 per cent per annum. In addition, Indonesia has had the patronage of wealthy foreign governments who rewarded Indonesia's crushing of communism by assisting with defence, trade and investment. Thus, until recently, ethical reform was never a condition of foreign support. The result was complacency, particularly among domestically owned firms producing for the huge local market rather than for export. However, recent and growing political instability, coupled with economic downturn, has provided at least some impetus for broader changes which, when coupled with Islam, may give rise to some positive change in terms of CSR. But the existing groundswell for political change has to some degree subsumed economic or business reform.

There is evidence that the social anarchy referred to by Jusuf Wanandi has infected both domestic and transnational corporations. A Canadian engineer and longtime resident in Indonesia has pointed to the increasingly degraded environmental, health and safety conditions in overseas-owned oil and gas plants and mines. His impressions were supported by more recent interviews with senior Ministry of Manpower officials. These sectors previously adhered to international performance standards, but there are growing signs of cynical disregard for the rule of law. Social breakdown may corrode the socially progressive steps taken by some TNCs.

Many Indonesian managers believe that good working conditions and environmental care are only available to rich foreign companies and do not bring them any immediate financial gain. The recent revelation by the owner of a factory that produces shoes for Reebok was a rare exception. He told reporters that the $\$ 2$ million he had to spend to meet compliance standards after an independent

$$
\text { Ekonomi, Sosial, dan Budaya }
$$


monitoring team had made its recommendations would be repaid in productivity and efficiency gains over three years.

Even if companies were interested, there are few existing avenues or forums (for example, trade unions) through which to share information, methods or models. The major Indonesian employers' group, APINDO, was founded as a conduit for patronage by one of Soeharto's sons, and is not regarded by all Indonesian business people, particularly women, as representative of their interests. APINDO officials indicated little knowledge of CSR, and only a cursory interest in further exploration of the subject. In recent years, seminars and conferences have been held by multilateral agencies on corporate governance, but the subject matter tends to favour the banks rather than the population and business at large.

\section{Who drives corporate social responsibility?}

It is clear that the driving force for social responsibility comes from outside Indonesia. The first major campaign to have an effect in Indonesia started in 1992/93 when the then head of the AFLI CIO office in Jakarta, working with the Jakarta Urban Mission, made contact with Nike workers. The subsequent campaign pointed out that while Nike's profit rose to over $\$ 180$ million per year, and their advertising budget for Michael Jordan alone was $\$ 20$ million, a Nike worker in Indonesia earned less than $\$ .90$ cents per day- $\$ 270$ per year (Suziani, 1999).

In 1992, the Levi Strauss manufacturing plant in Indonesia was the subject of a human rights report, which alleged that workers had been slapped and abused if their pace did not meet production targets. Adverse publicity caused Levi Strauss to take stern measures to ensure compliance to the company's Terms of Engagement. Since then the international consumer and anti-sweatshop movements have orchestrated continuing campaigns.

While the politics of the global anti-sweatshop movement are complex, and seemingly based on shifting alliances, several groups have emerged as having most influence in Indonesia. The US-based
Global Exchange is involved, as are the Fair Labor Association and the Students Against Sweatshops movement with their allies, the more radical Workers Rights Campaign. The Global Alliance, which represents World Bank and corporate interests, has just set up an office in Indonesia. In recent times the Fair Labor Association, with funding from the MacArthur Foundation, has begun to develop training for indigenous labour monitors, so that they can monitor codes of conduct. While most Indonesian labour groups care little about codes of conduct, the training was useful in a wider context, as it made some progress toward compensating a widening gap in technical assistance to Indonesia. Recently, several of the major TNCs operating in Indonesia (Ericsson, Nike, Unilever, BP, Deutsche Bank) agreed to become part of the United Nations-sponsored Global Compact, the aim of which is to promote labour, human rights and environmental principles.

\section{Corporate Responsibility and the Environment}

It is now understood that the biodiversity of the Indonesian archipelago comes close to that of the Amazon Basin (Barber, 1997). And like that of the Amazon Basin, Indonesia's biodiversity and ecological balance is being threatened by rapacious mining, palm oil and forestry activities. Under Indonesian law, any land not being used for agriculture, housing or industry is automatically owned by the state, nullifying traditional claims over land use (adat rights). This means that natural resources can be exploited without any sharing of profit with local communities.

Indonesia is a major world producer of tin, coal and copper. It has extraordinary reserves of iron sands, bauxite and phosphates. Its main revenue earner is gold, and it appears that alluvial diamonds will be profitable. The forests are abundant with hardwoods and cabinet timbers, such as teak. While this is essentially good news for a poor economy, in the absence of social or business ethics and in the presence of crony and military-led capitalism, the temptation for environmental devastation has always been present.

$$
\text { Ekonomi, Sosial, dan Budaya }
$$


Military economic interests and their support for Soeharto added a particularly ruthless element to ecological management in Indonesia. Recent evidence suggests that the military is still a leading player in the post-Soeharto era. After an Australian gold mine in North Sulawesi was taken over by local miners, for example, the area became been badly polluted by the mercury used to separate the gold from the ore. The practice threatens fragile reefs in Manado and the area's tourist industry that relies on the reefs, as well as the health of the miners and their families. Many of the miners work for senior military officials who prosper from the gold and diamonds that are smuggled out of the country. These generals reportedly threatened officers of the regional environmental agency, BAPEDALDA, when they attempted a clean-up.

Desperate for foreign investment, the new government recently agreed to allow mining in two of the most densely populated islands of the archipelago: Java and Bali. Not only are these two islands redolent with sites of great cultural and religious significance, they are already suffering environmental problems caused by large populations.

Despite international campaigns against Australian and American transnational companies in the main mines, the worst environmental damage is being done by regionally owned and Indonesian natural resource-based companies, some of them connected to the Indonesian military, with or without links to the Soeharto clan; others linked to Malaysian and Singaporean TNCs. The forest fires that annually send health-threatening smoke across the straits of Malacca into Singapore, Malaysia and Thailand are a mark of just how arrogantly negligent Indonesian (and Malaysian) corporations can be. They have proved to be largely immune to international and local pressures for some degree of social and environmental responsibility.

In collaboration with Indonesian elites, Malaysian and Singaporean transnational logging and oil palm companies have caused some of the worst environmental damage seen so far in Asia. An unpublished World Bank report warns that Sumatra's lowland forest will be extinct before 2005, thus reducing habitat for the Sumatran tiger and other indigenous species. Millions of hectares of forest in Sumatra and Kalimantan have been destroyed by fire in order to grow the oil palm. It is estimated that the destruction of one million hectares of peat swamp forest in Kalimantan, and the subsequent fires in peat seams, have set back by 10 years the carbon fixing capacity of pristine peat bogs and added 0.5 parts per million of carbon dioxide to the global atmosphere (Reiley, 2001). Furthermore, the suspended particulates and smoke from the fires have led to deaths and untold health problems among the peoples of Malaysia, Singapore and Indonesia. These acts of social irresponsibility threaten biodiversity, destroying sensitive habitats and robbing tribal peoples of their land.

\section{Tentative steps toward corporate environmental responsibility}

Certain institutions in Indonesia have taken some tentative steps to promote corporate environmental responsibility. Perhaps the bestknown voluntary initiatives of the 1990s were the PROKASIH programme and its successor, PROPER. Initiated by the Indonesian government with support from several donors, these programmes aimed to reduce water pollution from manufacturing industries. The programmes relied on the voluntary involvement of firms, regular collection and analysis of samples of liquid discharges, and monitoring by staff from BAPEDAL (the Environmental Impact and Management Agency) and provincial environmental offices. Analysis of discharge data prior to these programmes showed that the great majority ( 75 per cent) of liquid pollution was being discharged by just 20 per cent of the factories surveyed (Afsah and Vincent, 1997). Aware of the weak to non-existent pollution monitoring and enforcement capacity, the programmes targeted the industries that were known to be the main causes of water pollution. One of the declared aims was to apply pressure on firms to reduce pollution discharges by engaging other stakeholders, such as local communities directly affected by pollution as well as the wider market.

PROKASIH (the Clean River Program) was initiated in June 1989 in eight provinces. By 1994 it had expanded to 13 out of the 27 provinces, and the number of factories involved rose from 381 to 1,275 over the same period. Many were large businesses 
producing significant amounts of toxic products, such as chlorine. The programme's objective was to monitor the biological oxygen demand (BOD) levels in liquid pollution discharged into adjacent rivers and water bodies. Analysis of the results of the programme conducted in 1994 showed that declines in BOD levels, some of which were significant, were the result of pollution control efforts in only 25 per cent of factories. Overall, however, it was thought that the programme did not lead to an important change in pollution discharges from most factories.

Under Indonesian law, new companies are supposed to complete an ANDAL (Environmental Impact Assessment) with the assistance of a private consultant. In 1994, however, the World Bank admitted that the results were disappointing (World Bank, 1994). Private consultants now have a booming business in preparing what are often reassuring and inaccurate AMDALs. A World Bank official interviewed for this paper believed that TNCs have to work to realistic standards that can be measured by the local authorities, or at least develop feedback systems with government agencies in order to foster transfer of technology. Most existing voluntary initiatives emphasize end-of-pipe technology rather than point source control, which makes it cheaper and easier to monitor when inspectors come-companies can simply fit the device for inspection. The World Bank representative recognized that business ethics and CSR have to be recast in ways that economists and bankers understand, as they are in control of Indonesia's economic and trade recovery.

Indonesia concern with environmental issues, which was marked by the passing of several pieces of legislation. The World Bank (1994) implies that Indonesian environmental stewardship is not yet supported by political will or by practical resources. BAPEDAL does not yet enjoy the status of a line ministry, and its links with other relevant agencies such as Public Works, Forestry and Planning are poor, which weakens any systematic attempt at environmental protection. But more importantly, the agency still bows to the will of those traditionally in a position of power.

Despite considerable technical assistance,
BAPEDAL and associated agencies continue to experience difficulties in relation to their regulatory and monitoring activities. For example, for the past nine years radioactive waste has been buried in inappropriate areas, including football pitches in the densely populated region of Tanggerang, one of the satellite cities of Jakarta. The authorities are now aware that thorium nitrate is used by around 200 factories in Indonesia, but cannot enforce existing regulations (it should be sealed within concrete prior to disposal) in the absence of sufficient trained personnel or management co-operation. Further, although they have a new inspectorate and comprehensive legislation, ${ }^{74}$ they have been unable to stop breaches of the national zoning laws in places like Bali.

Some firms have taken a lead in environmentally responsible initiatives. Ciba Geigy, for example, which owns a large dye fabrication plant on the outskirts of Jakarta, was concerned about contaminated water being discharged into the river. The same properties that gave the dye its intense colour made it resistant to normal biological breakdown processes. A team of local and expatriate engineers devised a system by which wastewater was held in specific colour coded tanks, to enable a recycling process. By using previously colour-saturated water, they saved on production costs, as less dye was needed. Their production meets the most stringent European standard and at the same time has been the product of a joint approach to problem solving. Ciba Geigy argued that TNCs could benefit from pursuing the same environmental objectives at all their plants regardless of local regulatory requirements (Schmidheiny, 1992). It is unfortunate that up until now a mechanism to transfer this type of approach more widely and systematically does not exist.

The international cement company, Semex, recently took over Indonesia's PT Gresik's interests and immediately began to ameliorate the worst of the environmental problems - such as dust falloutcreated by the Indonesian company. At the time of writing, they had instituted a community development programme, working with local village members to identify priority issues in health and education.

$$
\text { Ekonomi, Sosial, dan Budaya }
$$


The oil and mining industry has come under considerable pressure to improve its environmental management systems. Some of the world's largest transnational oil and mining corporations operate in Indonesia: Caltex, Mobil, BP, Freeport-McMoRan, Agip, Newmont, Shell, Rio Tinto, Oppenheimer, Sun Oil, Total, Petromer and Conoco. All oil and gas operations have to enter into partnership with Pertamina, the state-owned corporation possessing the monopoly for national fuel supply and sales (Kemp, 2001).

A World Bank official and former mining engineer interviewed for this paper believed that the country of origin of a TNC is an important determinant of CSR in the mining industry and of how a mining company approaches social and environmental issues. US companies were less sensitive to local cultures, trade union structures and environmental imperatives, and tended to foster and enjoy political patronage that gave them immunity from regulatory interference. He used Kaltim Prima Coal (an Australian company) and Newmont mines (US-owned) as examples. While Kaltim rigorously observed safety issues and permitted trade unions, Newmont tended to ride roughshod over local cultures and was intolerant of trade unions. The newly commissioned Newmont mine had been closed for special education programmes conducted by the Division of Mine Safety after several workers were killed.

That being said, Australian mines are not immune from charges of impropriety. Most of the metalliferous mining companies are Australianowned. Despite Shell saying that it is inevitable, simply for pragmatic reasons, that oil and mining companies respond to green realities (Simpson, 2000), it appears that some of the mining companies operating in Indonesia have been less than scrupulous with environmental and community care. The Minerals Council of Australia has developed a Code for Environmental Management to which some 40 major mining companies are signatory. Like all codes of conduct, however, it is voluntary and the precepts are vague and general. While it refers to environmental management, it makes no reference to social or economic impacts. While there is no monitoring of compliance, signatory companies have to prepare annual reports on their own performance. There are no sanctions for non-compliance, and while the larger companies have signed, most of the smaller outfits have not (Atkinson, 2001). Atkinson proposes that codes cannot take the place of legislation and suggests that the Australian government should set standards for companies operating overseas. Further, a complaints mechanism should be established to enable those affected by the activities of Australian companies to put forward their grievances. His call has apparently been taken up by the national opposition party, which proposes "to review environmental practices and standards implemented by Australian mining companies overseas".

Two Indonesian and Australian researchers spent considerable time trying to understand the place Kaltim Prima Coal had in local politics and community in Kalimantan. They found that local people still tend to be excluded from decision making that affects their lives, and commented that "the ways in which TNCs operate are not suited to collective or community based problem solving". This may be because those who have to sign off on expenditure or decisions are geographically distant from the site, or they prefer to negotiate with the few familiar representatives. On the other hand, the people depended on the mine for mediation in disputes and for many of the services such as health, water supply, sanitation and education, normally the domain of governments. Kaltim Prima even supplied the local police with office equipment and cars (Kunanyagam and Young, 1998).

\section{Conclusion}

Two questions have been considered in this paper. First, do CSR and accompanying voluntary initiatives have the capacity to change how TNCs really behave in their day-to-day operations? Second, at this stage of its development, and in the context of the latest crisis, is CSR relevant to Indonesia? While the notion of CSR is not under question, its application and relevance are. It brings to mind Marie Antoinette's aphorism, suggesting that in our enthusiasm the West may be trying to distribute cake, when what is truly needed is bread.

When viewed in an overall cultural, economic and political context CSR remains an ideal in Indonesia. During the economic crisis

$$
\text { Ekonomi, Sosial, dan Budaya }
$$


economists repeatedly asserted that Indonesia's economic fundamentals were sound. The crisis, however, was certainly deepened by the fact that the social, legal and factors crucial to CSR were not sound. ${ }^{87}$ The current transformation is bringing instability, fear and violence. In such a context, it is hard to consider something as abstract as CSR. It is time, however, to begin to put into place the institutions, educational foundations and management training which are needed for business and political reform, and from which CSR may be a spin-off. Any broader application of CSR needs to stem from an indigenous belief in the necessity of such an institution, and not represent a mere shrug to another Western fashion.

At this point in Indonesian history, CSR itself can only remain an image projected onto a screen - an outline with little depth. While concepts such as governance and CSR are fashionable, generating a new language and teams of experts, Indonesia's difficulties are perhaps more basic and to do with simple national survival. As Faulkner (1995) points out, management is a newly emerging skill in Indonesia. The type of process-oriented cultural change within an organization, which CSR requires, infers high levels of skill and an active consultative process between equals - not in keeping with the patriarchal top-down leadership that characterizes Indonesian business and management structures in both TNCs and domestically owned firms.

While it is fair to say that CSR makes a positive contribution to the human rights of those working in TNCs, it is also fair to say that it only makes a difference to those few corporations targeted by consumers or who are already thinking ethically and responsibly. Other industries are not under such pressure. INFACT's efforts to draw attention to the global cigarette industries is to be admired, as not only does its product kill those who consume it, it is also a very hazardous industrynicotine and other chemicals being notable toxicants (INFACT 1998, Kemp, 2000). Workers die and people lose their land to construct international hotels, yet Nike still dominates the selective "consumer outrage index". Such anomalies and the somewhat piecemeal approach of the CSR movement should alert global citizens to the need for a more systematic approach. Some would advocate industry-specific global standards. But it is highly unlikely that nation states like Indonesia, Malaysia and Singapore, for instance, would succumb to such regulations.

That being said, the after-shock of the Indonesian economic crisis has required a reevaluation of economic and investment policy and the way business is run in Indonesia. The previous short-term thinking may have to make way for the type of longer-term pragmatic and visionary thinking required by genuine CSR and supported by Islamic business principles. A lot will depend on how deep the reform process goes. The "natural capitalist" approach taken by Ciba Geigy in its Indonesian dye plants also holds considerable promise as an adjunct and motivator for CSR, and illustrates Eddington's point, that there is no "onesize-fits-all" methodology (Eddington, 2000). Codes of conduct may in fact be regarded as a "onesize-fits-all solution".

Indonesia may be able to benefit from CSR, but it cannot rely on CSR to solve issues of exploitation, environmental devastation and poor labour standards, particularly when Western finance corporations are impervious to environmental or labour rights lobbying and community outrage. Furthermore, Indonesia cannot rely on codes of conduct and monitoring to maintain labour standards in all TNC-owned or co-opted plants. When companies such as Nike have their backs to the wall, they appeal not to their host nation or to the law, but to bodies such as the Fair Labor Association in the United States, that is, to monitors whose recommendations can be ignored or applied only in the premises evaluated. In the end, this can be regarded as simply an extension of industrial colonialism. When the fuss dies down, what is to stop companies turning a blind eye to monitoring? Besides, the increasing numbers of people prepared to buy brands in the Third World are beginning to compensate for lost consumers in the industrialized countries. While well-intentioned managers exist in many TNCs, they are often overruled by boards with have other priorities, not least the need to keep shareholders happy. At this juncture in its development, it appears that Indonesia can indeed "accommodate" the tenets of Western CSR, as it has

$$
\text { Ekonomi, Sosial, dan Budaya }
$$

1400 
accommodated the tenets of human rights. ${ }^{92}$ But in reality, the inherent conflicts between CSR and, in particular, political culture may ensure that in Indonesia implementation of CSR is merely cosmetic. Indonesia's recent history is littered with examples of agencies advocating the latest trend and congratulating Indonesia for illusory change. It is pertinent to ask whether CSR has anything more to offer Indonesia at this time than what could be offered by overall structural reform. While some would argue that CSR paves the way for political development (Rossouw, 1998), I contend that any effective implementation of CSR requires the machinery of an effective democratic government and civil society. The reverse would have corporations leading the process rather than the other way around.

It is also premature to speak of CSR in Indonesia when the tools of civil society are structurally and legislatively weak. With assistance from the ILO, Indonesia is beginning to put in place legislation that will enable more equitable collective bargaining, but this will take some time to establish and assumes that industrial bodies already have the skills to use the law to seek labour justice and that they are, in essence, free to act. This is not the case. The machinery of government is still captured by corporate interests and the indications are that corporate interests will strengthen their influence through established lines of political and business connections. Such interests are already lobbying, with IMF support, to reduce the benefits granted to workers by reformist elements. In the short term, trade unions in Indonesia should be actively supported and strengthened. It should no longer be acceptable to covertly or overtly undermine the rights of one of the cornerstones of the industrial partnership, particularly when their role in economic prosperity has been so adequately demonstrated (Standing, 1999).

\section{Bibliography}

Afsah, K. and J.R. Vincent. 1997. Putting Pressure on Polluters: Indonesian's PROPER Program, Harvard Institute for International Development (HIID), Asia Environmental Economics Seminar, Cambridge, Massachusetts.
Alatas, Syed Hussein. 1999. Corruption and the Destiny of Asia, Prentice Hall, Malaysia.

Atkinson, J. 2001. "Mind they neighbour", and "Get your act together Aussie!", Inside Indonesia, No. 65, January-March, pp. 4-7.

Barber, C. V. 1997. The Case Study of Indonesia, (summary), World Resources Institute, , www.library.utoronto.ca/pcs/state/indon.indo nsum.html.

Darley, W.K. and D.M. Johnson. 1993. Cross national comparison of consumer attitudes towards consumerism in four developing countries, Journal of Consumer Affairs, No. 27 , pp. 37-54.

Faulkner, G. 1995. Business Indonesia, Business and Professional Publishing, Sydney.

Friedman, M. 1970. The social responsibility of business is to increase its profits, New York Times, 13 September, pp. 122-126.

Goodfellow, R. 1997. Indonesian Business Culture: An Insiders Guide, BHA Asia.

Infact. 1998. Global aggression, the case for world standards and bold US action challenging Phillip Morris and RJR Nabisco, Infact's Peoples Annual Report, Apex Press, New York,.

Kemp, M. 2000.Working For Life: A Sourcebook for Women Industrial Workers, Isis Publications, Manila.

2001. Corporate Social Responsibility

in Indonesia. Cornell University ILR School. http://digitalcommons.ilr.cornell.edu/codes

Krugman, P. 1999. The Accidental Theorist and Other Dispatches from a Dismal Science, Penguin Books, London.

Kunanayagam, R. and K. Young. 1998. Mining, environmental impact and dependent communities, in P. Hirsch and C. Warren (eds.), The Politics of Environment in Southeast Asia: Resources and Resistance, Routledge, London.

Quazi, A. and D. O'Brien. 2000. An empirical test of a cross cultural model of corporate Ekonomi, Sosial, dan Budaya

1401 
responsibility, Journal of Business Ethics, No. 25, pp. 33-51.

Reiley, J. 2001. Kalimantans disaster, Inside Indonesia, No. 65, January-March, pp 12-13.

Rossouw, G. 1998. Establishing moral business culture in newly formed democracies, Journal of Business Ethics, No. 17, pp. 1563-1571.

Sawarjuno, T and R. Goodfellow. 1997. The Chinese Indonesians and Business, Indonesian Business Culture: An Insiders Guide, BHA Asia.

Simpson, J. 2000. Shell's Approach to Human Rights and Corporate Responsibility, Public Interest Advocacy Center. Seminar paper presented in Sydney, 30 October.

Standing, G. 1999. Global Labour Flexibility:
Seeking Redistributive Justice, Macmillan, London.

Suziani. 1999. Kasus Nike di Indonesia: Meneropong Kondisi Kerja Buruh Perusahaan Sepatu Olahraga, Yakoma-PGI and the Indonesian Sports Shoe Monitoring Group.

Schmidheiny, S. 1992. Changing Course: A Global Business Perspective on Development and the Environment, MIT Press, Cambridge, Massachusetts.

World Bank Indonesia. 1994. Development and the Environment, Washington, DC. 